\title{
Istanbul Bibliography 2020
}

\section{Compiled by Osman Kocabal and Deniz Özcan}

Adıgüzel, Hale. “Büyükada'da Sıradışı Üslupta Bir Yapı: Raimondo D’Aronco’nun Mizzi Köşkü Rekonstrüksiyonu." Sanat Tarihi Dergisi 29 (2020): 1-31.

Akan, Erkin. “Şehremini Cemil Paşa'nın İstanbul'un Çehresine Katkıları Üzerine Bir İnceleme.” Türk Dünyası Araştırmalart 125 (2020): 193-220.

Akcan, Esra. "Homo Economicus of the 'New Turkey': Urban Development of Istanbul in the 20oos." In Neoliberalism on the Ground: Architecture and Transformation from the 1960s to the Present, edited by Kenny Cupers, Catharina Gabrielsson and Helena Mattson, 383-407. Pittsburgh: University of Pittsburgh Press, 2020.

Akçura, Gökhan. İstanbul Şarkıları: Şehrin Müzikli Tarihinde Kazı Çalışmaları. Istanbul: Oğlak Yayıncılık ve Reklamcilik, 2019.

Akdeniz, Cüneyt. "Polis Mecmuası'nın 1919-1923 Yazılarına Göre İstanbul'da İşlenen Suç Çeşitleri." Atatürk Dergisi 9 (2020): 97-124.

Akınc1, Turan. İstanbul: Dersaadet (1453-1922). Istanbul: Remzi Kitabevi, 2020.

Aksoy Ertürkmen, Bengi Su, and Neşe Gurallar. “19. Yüzyılın İkinci Yarısında İstanbul Gemicilik Şenlikleri: Büyükada (Prinkipo) Regattaları ve Adanın Dönüşümü.” METU Journal of the Faculty of Architecture 37, no. 1 (2020): 1-31.

Altıntaş, Mustafa. Osmanlı İstanbul'unda Ta'âm Bişirüb Satanlar: Aş̧̧ılar, Başçılar, Büryancılar, Börekçiler, Tatlicilar (1500-1800). Istanbul: Kitap Yayınevi, 2020.

Altunyaldız Artun, Nur. Muhafaza/Mimarlk. Edited by Bilge Bal. Istanbul: Iletişim Yayınları, 2019.

Alwis, Anne P. Narrating Martyrdom. Rewriting Late-Antique Virgin Martyrs in Byzantium. Liverpool: Liverpool University Press, 2020.

Angelov, Dimiter. The Byzantine Hellene. The Life of Emperor Theodore Laskaris and Byzantium in the Thirteenth Century. Cambridge: Cambridge University Press, 2019.

Ar, Bilge. “İşgal İstanbul'unun Kentsel Dönüşümünü Beyaz Ruslar Üzerinden Okumak.” YILLIK: Annual of Istanbul Studies 1 (2019): 101-122.

Araz, Yahya, and İrfan Kokdaş. "In Between Market and Charity: Child Domestic Work and Changing Labor Relations in Nineteenth-Century Istanbul.” International Labor and Working-Class History 97 (Spring 2020): 81-108.

Araz, Yahya. Osmanlı İstanbul'unda Çocuk Emeği: Ev İçi Hizmetlerde İstihdam Edilen Çocuklar (1750-1920). Istanbul: Kitap Yayınevi, 2020.

Arentzen, Thomas, and Mary B. Cunningham. The Reception of the Virgin in Byzantium Marian Narratives in Texts and Images. Cambridge: Cambridge University Press, 2019.

Aretov, Nikolay. "Dreaming Constantinople: An Alternative Version of Petko Todorov and Nikolay Raynov." Études balkaniques 56, no. 2 (2020): 227-239.

Armağan, Mustafa. "Myrelaion Rotondası'nın Tarihi ve Güncel Durumunun Kentsel Arkeoloji Açısından İncelenmesi." Türkiye Bilimler Akademisi Kültür Envanteri Dergisi 21 (2020): 165-179.

Armstrong, Pamela. "The Earliest Glazed Ceramics in Constantinople: A Regional or International Phenomenon?" Journal of Archaeological Science: Reports 29 (2020).

https://doi.org/10.1016/j.jasrep.2019.102078.

Aurell, Jaume. Medieval Self-Coronations. The History and Symbolism of a Ritual. Cambridge: Cambridge University Press, 2020.

Ayar, Talip. "Il. Meşrutiyet Sonrası İstanbul Medreselerinde Talebeye Sunulan Iâşe Olanakları." Bilimname 41, no. 1 (2020): 131-158.

Aydıngün, Şengül, and Haldun Aydıngün. "İstanbul Küçükçekmece Göl Havzası'nın Tarihöncesi (Paleolitik-Erken Tunç Çağları).” Amisos 5 (2020): 7-30. 
Aydıngün, Şengül, Andreas Külzer, Ayber Enez, Błażej Stanisławski, Hakan Öniz, Hakan Kaya, Haldun Aydıngün, and Özlem Makaroğlu. "Ancient Reservoir at Athyra, Constantinople at Risk: The Value of Combined Historical, Archaeological and Geoarcheological Data." Mediterranean Archaeology and Archaeometry 20, no. 3 (2020): 27-46.

Aydıngün, Şengül., Y. C. Kurban, C. Ç. Yalçıner, A. Büyüksaraç, E. Gündoğdu, and E. Altunel. "HighResolution Ground Penetrating Radar Investigation of Yerebatan (Basilica) Cistern in Istanbul (Constantinople) for Restoration Purposes." Mediterranean Archaeology and Archaeometry 20, no. 3 (2020): 13-26. https://doi.org/10.5281/zenodo.3930402.

Aykaç, Pınar. "Archives as Fields of Heritage-Making in Istanbul's Historic Peninsula." International Journal of Islamic Architecture 9, no. 2 (2020): 361-387.

—_ "Kentsel Bağlamda Müzeleşme: Sultanahmet Bölgesinin Müze Alanına Dönüşümü.” Türkiye Bilimler Akademisi Kültür Envanteri Dergisi 21 (2020): 145-163.

. "The Commission for the Preservation of Antiquities and Its Role in the Appropriation of İstanbul's Diverse Heritage as National Heritage (1939-1953)." New Perspectives on Turkey 62 (2020): 75-99.

Aykut, Ebru. "Mekteb-i Tibbiye Numunehanesi'ndeki Anatomi Koleksiyonları ve Teratolojik Numuneler." Toplumsal Tarih 311 (November 2019): 42-47.

Balcı, Öykü Bahar, and Mehmet Sinan Kolay. "19.yy Başından Cumhuriyetin Kuruluşuna Kadar Olan Süreçte Beyoğlu ve Çevresinde Meydana Gelen Yangınların Galata Sarayı'nın Değişimine Etkileri.” Turkish Studies 15, no. 1 (February 2020): 31-55.

Balsoy, Gülhan. "The Solitary Female Refugees and the Widows' Asylum (Kırmızı Kışla) in Late Nineteenth-Century Istanbul." Journal of the Ottoman and Turkish Studies Association 6, no. 2 (2019): 73-90.

Barker, Hannah. That Most Precious Merchandise: The Mediterranean Trade in Black Sea Slaves, 1260-1500. Philadelphia: University of Pennsylvania Press, 2019.

Baş, Gülsen, Ayşegül Bekmez, Gülsün Ebiri, Mesut Gül, and Resul Yelen. İstanbul Davut Paşa Külliyesi Haziresi ve Mezar Taşları. Istanbul: Hiperlink Yayınları, 2019.

Başar, Dilek. "1924-1928 Yılları Arası İstanbul Şehremaneti Mecmuası'nda Şehircilik Açısından Su Konusu." Avrasya Incelemeleri Dergisi 9 (2020): 29-53.

Baysak, Erensu, Neşe Yorguner, Güler Kandemir, Işık Akyollu Denizman, and Yıldız Akvardar. "Is Early Marriage Practice a Problem for Women Living in Istanbul? A Qualitative Study." Archives of Women's Mental Health (2020). https://doi.org/10.1007/s00737-020-010673.

Behar, Cem. Orada Bir Musıki Var Uzakta...: XVI. Yüzyll İstanbulu’nda Osmanll/Türk Musıki Geleneğinin Oluşumu. Istanbul: Yapı Kredi Yayınları, 2020.

—_ "Inventors of Notation Systems in Seventeenth and Eighteenth-Century Istanbul: The Loneliness of the Long-Distance Runner." YILLIK: Annual of Istanbul Studies 1 (2019): 193-199.

Berberian, Houri. Roving Revolutionaries: Armenians and the Connected Revolutions in the Russian, Iranian, and Ottoman Worlds. Oakland: University of California Press, 2019.

Berksoy, Funda. "Art Exhibitions in Munich and Istanbul (1909-18): Cultural Events as Part of German Imperialist Policies." Journal of the Ottoman and Turkish Studies Association 7, no. 1 (2020): 173-204.

Betancourt, Roland. Byzantine Intersectionality: Sexuality, Gender, and Race in the Middle Ages. Princeton: Princeton University Press, 2020

Bilen, Hakkı. Moda’nın Mülteci Alman Profesörleri. Istanbul: Kadıköy Belediyesi Kültür Yayınları, 2019.

Bingül, Şeyhmus. "Alemdar Gazetesi'ne Göre 1911 Yazında İstanbul'un Kolera ile İmtihanı." Mersin Üniversitesi Tip Fakültesi Lokman Hekim Tip Tarihi ve Folklorik Tip Dergisi 10 (2020): 360-377.

__. "Il. Abdülhamid Döneminde İstanbul'da Bulaşıcı ve Salgın Hastalıklara Karşı Alınan Tedbirler: Mektep Tatilleri.” Yüzüncü Yll Üniversitesi Sosyal Bilimler Enstitüsü Dergisi (2020): 77-104.

Blanchet, Marie-Hélène. "Les recommandations du patriarche de Constantinople aux chrétiens orthodoxes de l'Empire ottoman en 1477." In Les Ottomans par eux-mêmes, edited by Elisabetta Borromeo and Nicolas Vatin, 53-64. Paris: Les Belles Lettres, 2020.

Bodin, Helena. “The clamour of Babel, in all the tongues of the Levant': multivernacular and multiscriptal Constantinople around 1900 as a Literary World." Textual Practice 34, no. 5 (2020): 783-802.

Bouras-Vallianatos, Petros. Innovation in Byzantine Medicine. The Writings of John Zacharias Aktouarios (c. 1275-c. 1330). Oxford: Oxford University Press, 2020. 
Breüning, Hans Jacob. Breüning Seyahatnamesi: Doğu Ülkelerine Yolculuk; Istanbul 1579. Translated by Selma Türkis Noyan. Istanbul: Kitap Yayınevi, 2020.

Brooks, Sarah T. The Art of Death in Byzantium: Funerary Art and Architecture, 1204-1453. London: Routledge, 2019.

Bulut, Ergin, Başak Can, and Nurçin Ileri. "Cementing Hegemony in New Turkey: The Construction Spectacle of Istanbul and the Rise of Right-Wing Masculine Populism." In Spaces of New Colonialism: Reading Schools, Museums, and Cities in the Tumult of Globalization, edited by Cameron McCarthy, Koeli Moitra Goel, Ergin Bulut, Warren Crichlow, Brenda Nyandiko Sanya, and Bryce Henson, 121-140. Bern: Peter Lang Publishing, 121-140.

Can, Mustafa. "Osmanlı Devleti’nde Eski Bir Türk Geleneği: Çanak Yağması.” Milli Folklor 16, no. 125 (2020): 150-162.

Ceylan, Nurbike. "Cevri Kalfa ve Mektebi." Insan ve Sosyal Bilimler Dergisi 2, no. 2 (2019): 331-347.

Chitwood, Zachary. "Muslims and Non-Orthodox Christians in Byzantine Law until ca. 110o." In Empire and Legal Thought: Ideas and Institutions from Antiquity to Modernity, edited by Edward Cavanagh, 167-188. Leiden: Brill, 2020.

Chrysos, Evangelos. "The Council of Constantinople in 869-70: A Minority Council." Annuarium Historiae Conciliorum 49, no. 1 (April 2020): 139-161.

Constantinou, Stavroula, and Christian Høgel, eds. Metaphrasis: A Byzantine Concept of Rewriting and Its Hagiographical Products. Leiden: Brill, 2020. https://doi.org/10.1163/9789004438453.

Crapper, Martin. "The Valens Aqueduct of Constantinople: Hydrology and Hydraulics." Water History (2020). https://doi.org/10.1007/s12685-020-00254-4.

Crawford, Peter. Roman Emperor Zeno: The Perils of Power Politics in Fifth-Century Constantinople. Yorkshire: Pen \& Sword Military, 2019.

Crow, James. "Constantinople in the Long Sixth Century." In Asia Minor in the Long Sixth Century: Current Research and Future Directions, edited by Jacobs Ine and Elton Hugh, 167-18o. Oxford: Oxbow Books, 2019.

Çağman, Engin. “Osmanlı Döneminde İstanbul'da Modern Bir Mezbaha Kurma Teşebbüsü.” FSM İlmi Araştırmalar Insan ve Toplum Bilimleri Dergisi 15 (2020): 33-62.

Çakıcı, Mustafa. Plan, Kroki ve Haritalarda: Kağıthane. Istanbul: Kağıthane Belediyesi, 2019.

Çamlı, Emine Z. “Beşiktaş 1o No'lu Şer'iyye Sicili’nin Tanıtımı ve Tasnifi.” Vakanüvis - Uluslararası Tarih Araştırmaları Dergisi 5 (2020): 18-73.

Çavuşoğlu, Erbatur, and Julia Strutz. "From Kayabaşı to Kayaşehir - A City Grows 'Out in the Sticks.” In Massive Suburbanization: (re)building the Global Periphery, edited by K. Murat Güney, Roger Keil, and Murat Üçoğlu, 165-18o. Toronto: University of Toronto Press, 2019.

Çaylı, Eray. İklimin Estetiği: Antroposen Sanatı ve Mimarlı̆̆ı Üzerine Denemeler. Istanbul: Everest Yayınları, 2020.

Çelik, Semih. "Science, to Understand the Abundance of Plants and Trees: The First Ottoman Natural History Museum and Herbarium, 1836-1848." In Environments of Empire: Networks and Agents of Ecological Change, edited by Ulrike Kirchberger and Brett M. Bennett, 85-102. Chapel Hill: University of North Carolina Press, 2020.

Çelik, Zeynep. Avrupa Şark’ı Bilmez: Eleştirel Bir Söylem (1872-1932). Istanbul: Koç Üniversitesi Yayınları, 2020.

Çete, Aslı. "Hafıza, Tatlar ve Sesler. İki Yazar, İki Şehir: İstanbul ve Selanik." Litera 30, no. 1 (2020): 245-266. Çıpa, Erdem H. Yavuz'u Yaratmak: Osmanlı Dünyasında Saltanat Veraseti: Meşruiyet ve Tarihi Hafiza. Translated by Zeynep Rona. Istanbul: Kitap Yayınevi, 2020.

Çiftçi, Yasemin. Osmanlı Istanbul'unun Ikki Asırlk Gayrimenkul Portresi (150o-170o). Ankara: Gazi Kitabevi, 2020.

Dağoğlu, Özlem Gülin. “Mihri Rasim and the Founding of the Women's Fine Arts Academy, İnas Sanayi-i Nefise Mektebi: a Double-edged New Social Reality." Journal of the Ottoman and Turkish Studies Association 6, no. 2 (2019): 33-54.

Danış, Didem, and Yaşar Adnan Adanalı, eds. "Mekanda Adalet ve Yaşl1lık." Special issue, Beyond.Istanbul 5 (2019).

Dannies, Kate. “'A Pensioned Gentleman': Women's Agency and the Political Economy of Marriage in Istanbul during World War l." Journal of the Ottoman and Turkish Studies Association 6, no. 2 (2019): 13-31. 
Dişli, Gülşen, and Zuhal Özcan. "A Comparative Research on Space of Women in Prayer Place Interiors of Celestial Religions: Cases from Istanbul.” Gazi University Journal of Science 33, no. 2 (June, 2020): 279-295.

Dogramac1, Burcu. "Arrival City Istanbul: Flight, Modernity and Metropolis at the Bosporus. With an Excursus on the Island Exile of Leon Trotsky." In Arrival Cities: Migrating Artists and New Metropolitan Topographies in the 2oth Century, edited by Burcu Dogramac1, Hetschold Mareike, Lugo Laura Karp, Lee Rachel, and Roth Helene, 205-226. Leuven: Leuven University Press, 2020.

Doğan, Evinç, Evren Doğan, and Edina Ajanovic. "Kahvehanelerin Kent Belleğindeki Yeri: İstanbul'daki Kahvehanelerin ve Belgrad'daki Kafanaların Karşılaştırmalı Analizi.” Istanbul University Journal of Sociology 40, no. 1 (2020): 443-465.

Durmaz Ekenler, Melike Selin, and Ulaş Bayraktar, eds. "Mekanda Adalet ve Müşterekler." Special issue, Beyond.Istanbul 6 (2019).

Dündar, Necip, and Reyhan Toplu. "Research on Immigrant Child Labour: Example of Kanarya Region in Istanbul" Avrasya Sosyal ve Ekonomi Araştırmaları Dergisi 7, no. 3 (2020): 63-75.

Enlil, Zeynep, and İclal Dinçer. "Residential Experiences in Times of Shifting Housing Regimes in Istanbul." In The Self-Build Experience: Institutionalization, Place-Making and City Building, edited by Salet Willem, D’Ottaviano Camila, Majoor Stan, Bossuyt Daniël and Yiftachel Oren, 167-19o. Bristol: Bristol University Press, 2020.

Erdinçli, Ihsan. "İstanbul Meyhânelerinde Sıra Dış1 Eğlenceler: 17. Yüzyıldan 20. Yüzyıla Müzik, Raks ve Cinsellik." Tarih Incelemeleri Dergisi 35, no. 1 (2020): 101-132.

Eren, Faruk. Kayıp Bir Devrimin Hikayesi: Bir Zamanlar Hasköy'de. Istanbul: Iletişim Yayınları, 2019.

Erensü, Sinan, ed. "İstanbul Yollarında Kentsel Politik Ekoloji." Special issue, Beyond.Istanbul 4 (2019).

Ersoy, Ahmet A. "Neo-Ottomanism in the Age of Digital Media." Red Thread 5 (2020). https://red-thread. org/en/current-issue/

Ertuğrul, Özkan. "Mimarlık Tarihi İçinde İstanbul Bizans Su Mimarisi Durumu -Il-." Meriç Uluslararası Sosyal ve Stratejik Araştırmalar Dergisi 4, no. 9 (2020): 74-136.

Esmer, Mine ve Arzu Ulaş. "Arşiv Belgeleri Işı̆̆ında 19. Yüzyılın İkinci Yarısından 1894 Depremi Sonrasına Fethiye Camii Onarımları." Sanat Tarihi Dergisi 29 (2020): 81-95.

Etker, Şeref. "İstanbul'un Ilk Verem Savaşımı Derneği: Ligue contre la Tuberculose (Phitisie pulmonaire) de Constantinople." Osmanlı Bilimi Araştırmaları 21, no. 2 (2020): 1-23.

Falcasantos, Rebecca Stephens. Constantinople: Ritual, Violence, and Memory in the Making of a Christian Imperial Capital. Oakland: University of California Press, 2020.

Faroqhi, Suraiya. "Made in Istanbul, Delhi or Agra': Serving Imperial and Princely Courts in the Ottoman and Mughal Worlds." In Turkish History and Culture in India, edited by A.C.S. Peacock and Richard Piran McClary, 299-338. Leiden: Brill, 2020. https://doi.org/10.1163/9789004437364_012.

Feldman, Walter. “The Emergence of Ottoman Music and Local Modernity.” YILLIK: Annual of Istanbul Studies 1 (2019): 173-179.

Firat, Hasan Baran. "Dönemlendirme Çalışmaları ve Osmanlı-Türk Müziği Tarihyazımı: Bir Bilanço Denemesi." YILLIK: Annual of Istanbul Studies 1 (2019): 145-164.

Fliche, Benoît, and Manoël Pénicaud. "Votive Exopraxis: Muslim Pilgrims at a Christian Orthodox Monastery (Büyükada, Istanbul)." Common Knowledge 26, no. 2 (2020): 261-275.

Fuhrmann, Malte. Port Cities of the Eastern Mediterranean: Urban Culture in the Late Ottoman Empire. Cambridge: Cambridge University Press, 2020.

Garzaniti, Marcello. "Methodius between Rome and Constantinople: The Return of the Moravian Archbishop to the Byzantine Capital (Vita Methodii, ch. XIII)." Slavia - časopis pro slovanskou filologii 89, no. 2 (2020): 121-131.

Gerber, Jane S. "Reconstructing Sephard in Istanbul and Salonica 1492-160o." In Cities of Splendour in the Shaping of Sephardi History, 171-213. Liverpool: Liverpool University Press, 2020.

Gingeras, Ryan. Eternal Dawn: Turkey in the Age of Atatürk. Oxford: Oxford University Press, 2019.

Giray Küçük, Sezgi. "istanbul ve Tekirdağ Rüstem Paşa Camilerinin Konum ve Mimari Özelliklerine Göre Karşılaştırmalı Olarak İncelenmesi.” Sanat-Art Dergisi 13 (2020): 117-141.

Gölönü, Berin. "From Graveyards to the 'People's Gardens." In Commoning the City: Empirical Perspectives on Urban Ecology, Economics and Ethics, edited by Derya Özkan and Güldem Baykal Büyüksaraç, 104-122. London: Routledge, 2020. 
Greve, Martin. Anlatılamazı Ifade Etmek: Yeni Dersim Sound'unun Oluşumu. Istanbul: Tarih Vakfı, 2019.

Griebeler, Andrew. "The Serpent Column and the Talismanic Ecologies of Byzantine Constantinople." Byzantine and Modern Greek Studies 44, no. 1 (2020): 86-105. https://doi.org/10.1017/byz.2019.25.

Griffin, Sean. The Liturgical Past in Byzantium and Early Rus. Cambridge: Cambridge University Press, 2020.

Gritchenko, Alexis. Istanbul'da İki Yıl 1919-1921: Bir Ressamın Günlüğü. Translated by Ali Berktay. Istanbul: Yapı Kredi Yayınları, 2020.

Gruber, Christiane. Osmanlı - İslam Sanatında Tapınma ve Tilsım. Istanbul: Yapı Kredi Yayınları, 2020.

Gullo, Arianna. "Writing Classicizing Epigrams in Sixth-Century Constantinople: The Funerary Poems of Julian the Egyptian." In The Genres of Late Antique Christian Poetry, edited by Fotini Hadjittofi and Anna Lefteratou, 59-74. Berlin: De Gruyter, 2020. https://doi.org/10.1515/9783110696219-003.

Güçlü, Özlem. "İstanbul Sokaklarında Türler Karşılaştığında: Kedi’nin Temizliği, Taşkafa'nın Hayaleti.” In Şehir ve Hayvan, edited by Ayten Alkan, 131-146. Istanbul: Patika Kitap, 2020. Reviewed in YILLIK: Annual of Istanbul Studies 2 (2020), by Onur İnal.

Güler, Ayşenur, and Vita Susak. Alexis Gritchenko: İstanbul Yilları. Translated by Yiğit Adam, Beyza Altay, Ali Berktay, Serra Yentürk. Istanbul: Vehbi Koç Yayınları, 2020.

Günay, Reha. Mimar Sinan Neden Bir Tasarım Dehasıdır? Istanbul: YEM Yayın, 2020.

Gündüz, Mehmet. "Suriçi’ndeki Yapılaşmanın Tarihi İstanbul Çeşmeleri Üzerindeki Etkisi ve Çeşmelerin Mevcut Durumu." Kent Akademisi 13, no. 1 (2020): 146-162.

Günergun, Feza. “On Dokuzuncu Yüzyıl İstanbul'unda İki Doğa Tarihi Müzesi: Mekteb-i Tibbiye-yi Şahane ve Darüşşafaka Koleksiyonları.” Toplumsal Tarih 311 (November 2019): 48-54.

Güney, K. Murat. "Building Northern Istanbul: Mega-Projects, Speculation and New Suburbs." In Massive Suburbanization: (re)building the Global Periphery, edited by K. Murat Güney, Roger Keil, and Murat Üçoğlu, 181-200. Toronto: University of Toronto Press, 2019.

Güven, Uğur Zeynep, Yunus Kaya, and Andrew J. Perrin. "Music, City and Social Change: A Study of Musical Preferences in a Former Suburb of Istanbul." Journal of Economy Culture and Society 61 (2020): 107-123. https://doi.org/10.26650/JECS2019-0075.

Güven, Uğur Zeynep. Music, City and Culture: An Ethnographic Study of the Rebetiko Music Scene in Istanbul. Istanbul: Libra Kitap ve Yayıncilık, 2020.

Gzoyan, Edita, Regina Galustyan, and Shushan Khachatryan. "Reclaiming Children After the Armenian Genocide: Neutral House in Istanbul.” Holocaust and Genocide Studies 33, no. 3 (Winter 2019): 395-411.

Hacısalihoğlu Ersoy, Neriman. "Sultan Mehmed Reşad Döneminde İstanbul'daki Bulgar Cemaati: Nüfus, Yerleşim ve Ekonomi.” Tarih Dergisi, no. 71 (2020): 407-428.

Hadodo, Matthew John. "Cosmopolitan Constantinopolitans: Istanbul Greek Language and Identity." PhD diss., University of Pittsburgh, 2020.

Halff, Maarten. "The Pope's Agents in Constantinople: Eugenius IV's Legation on the Eve of the Council of Ferrara-Florence (1438-1439)." Mediterranea International Journal on the Transfer of Knowledge 5 (2020): 91-151.

Han, Ayhan. "Osmanlı Döneminde Yerebatan Sarnıcı ve Mahallesi." YILLIK: Annual of Istanbul Studies 1 (2019): 81-99.

Hart, Kimberly. "Empatinin Kültürel Boyutları Üzerine: Sokak Hayvanları ve İstanbul.” In Şehir ve Hayvan, edited by Ayten Alkan, 97-130. Istanbul: Patika Kitap, 2020. Reviewed in YILLIK: Annual of Istanbul Studies 2 (2020), by Onur İnal.

Harootunian, Harry. The Unspoken as Heritage: The Armenian Genocide and Its Unaccounted Lives. Durham: Duke University Press, 2019.

Hazırbulan, Tahsin. "Sadaka-i Sultânî Defterine Göre Havâss-ı Refîa'da Mahalleler ve Fakirleri." Tarih ve Gelecek Dergisi 6 (2020): 89-117.

Herzog, Christoph, and Richard Wittmann, eds. Istanbul-Kushta-Constantinople: Narratives of Identity in the Ottoman Capital, 1830-1930. London: Routledge, 2020.

Houston, Christopher. Istanbul, City of the Fearless: Urban Activism, Coup d'État, and Memory in Turkey. Oakland: University of California Press, 2020. Reviewed in YILLIK: Annual of Istanbul Studies 2 (2020), by Sinan Erensü.

Irmak, Hüseyin, and Rıfat Behar. Seyahatnamelerde Kağıthane. Istanbul: Kağıthane Belediyesi, 2019. Irmak, Hüseyin. Kağıthane Tarihi Eser Restorasyonları. Istanbul: Kağıthane Belediyesi, 2019. 
Brill, 2019. https://doi.org/10.1163/9789004392083.

İkizoğlu Erensü, Aslı, and Yunus Doğan Telliel, eds. “Mekanda Adalet ve Mültecilik.” Special issue, Beyond. Istanbul 7 (2019).

İleri, Nurçin. “Kayıp bir Müzenin İzinde: Robert Kolej'in Bilimsel Koleksiyonları.” Toplumsal Tarih 311 (November 2019): 40-57.

İnanan, Filiz, Mehmet Akçınar, and Tuğba Akçınar. “iznnik / Nikaia, İstanbul Kapı Kazıları'ndan Pişmiş Toprak Kandiller.” Art-Sanat Dergisi, no. 14 (2020): 159-184.

İnce, Ziya, and Mustafa Sağdıç. "Osmanlı'dan Günümüze Öğretmen Okullarında Coğrafya Öğretmen Eğitimi: İstanbul Darülmuallimîn’i (Çapa Öğretmen Okulu) Örneği.” Turkish Studies 15, no. 1 (2020): 263-282. İpek Illçin, Hasret. "Balkan Savaşları Sırasında Hilâl-i Ahmer Cemiyeti’nin İstanbul'daki Faaliyetleri." Turkuaz Uluslararası Türk Dünyası Bilimsel Araştırmalar Dergisi 1 (2020): 70-81.

İşkorkutan Erdoğan, Sinem. The 1720 Imperial Circumcision Celebrations in Istanbul. Leiden: Brill, 2020.

_. "Nahıls and Candy Gardens in the 1720 Imperial Festival." Muqarnas 37 (2020): 179-208.

Kad1, İsmail Hakk1, and A.C.S. Peacock. "Royal Visits to Istanbul, 1891-1909." In Ottoman-Southeast Asian Relations: Sources from the Ottoman Archives, 328-417. Leiden: Brill, 2019.

Kafescioğlu, Çiğdem. "Sokağın, Meydanın, Şehirlilerin Resmi: On Altıncı Yüzyıl Sonu İstanbul'unda Mekân Pratikleri ve Görselliğin Dönüşümü." YILLIK: Annual of Istanbul Studies 1 (2019): 7-43.

__. "Lives and Afterlives of an Urban Institution and Its Spaces: The Early Ottoman 'İmāret as Mosque." In Historicizing Sunni Islam in the Ottoman Empire, c. 1450-c. 1750, edited by Tijana Krstić and Derin Terzioğlu, 255-307. Leiden: Brill, 2020. https://doi.org/10.1163/9789004440296_009.

_. "Picturing the Square, Streets, and Denizens of Early Modern Istanbul: Practices of Urban Space and Shifts in Visuality." Muqarnas 37 (2020): 139-177. https://doi.org/10.1163/22118993-00371Po6.

Kala, Eyüp Sabri. "Fatih Külliyesi ve Ayasofya-i Kebir Vakfı (Hayır Müesseseleri, Hizmetleri, Görevlileri ve Yönetimi)." FSM İlmi Araştırmalar İnsan ve Toplum Bilimleri Dergisi, no. 15 (2020): 99-130.

Kalafat, Murat. "Üsküdar: Kadınların Prestij Sahası." Art-Sanat Dergisi 14 (2020): 185-209.

Kamouzis, Dimitris. Greeks in Turkey. Elite Nationalism and Minority Politics in Late Ottoman and Early Republican Istanbul. London: Routledge, 2020.

Kara, Ülkü. "A Group of One-Handled 'Sardis Type' Amphorae from the Excavations at Küçükçekmece Lake Basin (Bathonea?).” OLBA 28 (2020): 421-438.

Karaağaçlığlu, Fezanur. “Epidemics, Urban Life, and Sanitation: Pera and the End of the Plague.” Master's thesis, Boğaziçi University, 2019.

Karadavut, Nilüfer. "Bâkî ve Nedîm Dîvânı'nda İstanbul Üzerine Mukayeseli Bir İnceleme.” Uluslararası Sosyal Bilimler Akademi Dergisi, no. 3 (2020): 460-48o.

Kayhan Kılıç, Seyhan. "Understanding A Displaced Community and Its Entangled Identity: Religious Rituals of Alevis in Istanbul." Journal of Alevism-Bektashism Studies 21 (June 2020): 3-38.

Kayhan Müldür, Sezen. "Postmodern Kentleşme ve Yaratıcı Ekonomi: İstanbul'da Medya Endüstrileri." Idealkent 11 (2020): 986-1009. https://doi.org/10.31198/idealkent.654491.

Keleş, Muhammet. “Şems Gazetesi ve İstanbul'daki İranlılar.” Tarih Araştırmaları Dergisi 39, no. 64 (2020): 443-453. https://doi.org/10.35239/tariharastirmalari.742701.

Khan, Abdul Zahoor, Syed Akmal Hussain Shah, Abdul Basit Mujahid and Muhammad Raza Taimoor. "Historiography of the Arab Muslim's Barricade of Constantinople: A Critical Appraisal." Journal of the Research Society of Pakistan 57, no. 1 (2020): 1-15.

Kiremitçiyan, Teni. “Arşiv Belgelerine Göre Hasköy'ün Günümüze Ulaşamayan Ermeni Eğitim Yapıları.” Sanat Tarihi Ylllı̆ı 29 (2020): 145-169.

Kitapçı Bayrı, Buket. "The 1oth International Congress of Byzantine Studies, Istanbul, September 15-21, 1955." YILLIK: Annual of Istanbul Studies 1 (2019): 123-144.

— ed. "Günümüz İstanbul'unda Bizans." Special issue, Toplumsal Tarih 308 (August 2019).

Kıygı, Gizem. "The Transformation of Beyoğlu Muslim Cemetery: Sanitizing, Beautifying and Reproducing the Memory of the City in the Nineteenth Century." Master's thesis, Boğaziçi University, 2019.

Kocaman, Meltem. "Scientific Instrument Retailers in Istanbul in the Nineteenth Century, and Verdoux's Optical Shop." In Scientific Instruments between East and West, edited by Neil Brown, Silke Ackermann, and Feza Günergun, 240-256. Leiden: Brill, 2019. https://doi.org/10.1163/9789004412842_015.

Kocatürk, Önder. İstanbul'da Sel ve Fırtına (1889-1924). Istanbul: Boğaziçi Yayınları, 2019. 
Koldemir, Birsen, and Cengiz Kahraman. "Ulaşım ve Ticaret Coğrafyası Açısından Istanbul Limanları." Elektronik Sosyal Bilimler Dergisi 19, no. 76 (January 2020): 1931-1949. https://doi.org/10.17755/esosder.645740.

Kostov, Alexandre. "Lighting in Ottoman Constantinople Until the First World War." Études balkaniques 56, no. 2 (2020): 240-258.

Kök, Elif. “Yeniçeri Müzesi’ne Ait Yeni Bulunan Bir Çizim.” Akdeniz Sanat 13 (2019): 265-276.

Köksal, Yonca, and Mehmet Polatel. "A Tribe as an Economic Actor: The Cihanbeyli Tribe and the Meat Provisioning of İstanbul in the Early Tanzimat Era." New Perspectives on Turkey 61 (2019): 97-123.

Köse, Fatih. "1756 İstanbul Yangını." Mevzu: Sosyal Bilimler Dergisi 2 (September 2019): 191-213.

Kukjalko, Brigita. "The Study of Ancient Greek Texts in Early Ottoman Constantinople.” Byzantina Symmeikta 30 (2020): 283-306. https://doi.org/10.12681/byzsym.15713.

Kurtaran, Uğur. "Heinrich Friedrich Von Diez’in İstanbul Elçiliği ve Faaliyetleri (1784-1790)." Ankara Üniversitesi Sosyal Bilimler Fakültesi Dergisi 75, no. 1 (2020): 127-162.

Kuru, Selim Sırrı, and İrvin Cemil Schick. "Les gitons d'Istanbul à la fin du XVIIle siècle." In Les Ottomans par eux-mêmes, edited by Elisabetta Borromeo and Nicolas Vatin, 89-99. Paris: Les Belles Lettres, 2020.

Kuş, Ayşegül. "Under the Light of the Population Register Dated 1857. An Evaluation Upon the SocioEconomic Lives of the Gypsy Living in Istanbul.” Selçuk Üniversitesi Sosyal Bilimler Enstitüsü Dergisi 43 (2020): 49-61.

Kuyumciyan, Lara, ed. "Mekânda Adalet ve Beyoğlu." Special issue, Beyond.Istanbul 9 (2020).

Küçük, Emir. "Urban Parks of Istanbul in the late Ottoman Empire: Constructed Nature for Recreation Aims.” Master's thesis, Boğaziçi University, 2019.

Küçük, Harun. Science without Leisure: Practical Naturalism in Istanbul, 1660-1732. Pittsburgh: University of Pittsburgh Press, 2020.

Küskü, Firat. "Il. Abdülhamid Devrinde Kâğıthane Mesiresi." Vakanüvis, Uluslararası Tarih Araştırmaları Dergisi 5, no. 2 (2020): 841-867. https://doi.org/10.24186/vakanuvis.767462.

Lam, Andrea Olsen, and Rossitza Schroeder, eds. The Eloquence of Art: Essays in Honour of Henry Maguire. London: Routledge, 2020. https://doi.org/10.4324/9781351185592.

Lazaris, Stavros. A Companion to Byzantine Science. Leiden: Brill, 2020.

Lazos, Panagiotis, George N. Vlahakis, and Constantine Skordoulis. "Instruments and Laboratories in the Schools of the Greek Community of Istanbul, 1850-1960." In Scientific Instruments between East and West, edited by Neil Brown, Silke Ackermann, and Feza Günergun, 168-186. Leiden: Brill, 2019. https://doi.org/10.1163/9789004412842_011.

Leidholm, Nathan. "Artaxerxes in Constantinople: Basil l's Genealogy and Byzantine Historical Memory of the Achaemenid Persians." Greek, Roman, and Byzantine Studies 6o, no. 3 (2020): 444-471.

Leonard, Benjamin. "Hagia Sophia's Hidden History." Archaeology 73, no. 4 (2020): 24-31.

Leonte, Florin. Imperial Visions of Late Byzantium: Manuel II Palaiologos and Rhetoric in Purple. Edinburgh: Edinburgh University Press, 2020. Reviewed in YILLIK: Annual of Istanbul Studies 2 (2020), by Paul Magdalino.

Lorenz, Beyza. "Novel Anxieties: An Ottoman Counter-discourse on Time and Space." Comparative Studies of South Asia, Africa and the Middle East 40, no. 2 (2020):387-40o. https://doi.org/10.1215/1089201X-8524303.

Loukaki, Argyro, ed. Urban Art and the City: Creating, Destroying, and Reclaiming the Sublime. New York: Routledge, 2020.

Maden, Nafiz. "Historical Aurora Borealis Catalog for Anatolia and Constantinople (HABcAC) during the Eastern Roman Empire Period: Implications for Past Solar Activity." Annales Geophysicae 38, no. 4 (2020): 889-899. https://doi.org/10.5194/angeo-38-889-2020.

Mamalı, Taybuğa Aybars. "Geç Osmanlı İstanbul'unda Tiyatrolar ve Denetim.” Toplumsal Tarih Dergisi 332 (October 2020): 16-22.

Mars, Evgenia. Abdülhamid İstanbul'unda Bir Kadın Seyyah. Translated by Hüseyin Mevsim. Istanbul: Kitap Yayınevi, 2019.

Martins De Jesus, Carlos A. "The Nude Constantinople: Masterpieces of Greek Sculpture at Byzantium According to the Greek Anthology." In Greek Art in Motion: Studies in honour of Sir John Boardman on the occasion of his goth Birthday, edited by Rui Morais, Delfim Leão, Diana Rodríguez Pérez, and Daniela Ferreira, 78-84. Oxford: Archaeopress Archaeology, 2019.

Masson, Gemma. "The Urban Jannisary in the Eighteenth-Century Istanbul." PhD diss., University of Birmingham, 2019. 
Melichar, Petra. Empresses of Late Byzantium: Foreign Brides, Mediators and Pious Women. Berlin: Peter Lang, 2019.

Mellas, Andrew. Liturgy and the Emotions in Byzantium. Compunction and Hymnody. Cambridge: Cambridge University Press, 2020.

Melvani, Nicholas. "Patronage in Constantinople after 1453." In En Sofía Mathitéfsantes: Essays in Byzantine Material Culture and Society in Honour of Sophia Kalopissi-Verti, edited by Charikleia Diamanti and Anastasia Vassiliou, 412-26. Summertown: Archaeopress, 2019.

Memiş, Şefik. "Unutulanları Hatırlamak için Yapılan Fuar: 1863 Sergi-i Umûmî-i Osmanî [Osmanlı Genel Sergisi]." Mavi Atlas 8, no. 1 (2020): 189-214. https://doi.org/10.18795/gumusmaviatlas.708719.

Meral, Safa, and Emre Kishalı. "Mimarlık Tarihi ve Mimari Koruma Ara Kesitinde Bir İnceleme: Üsküdar Şemsi Ahmed Paşa Külliyesi." Art-Sanat Dergisi 13 (2020): 313-334.

Mériaux, Charles. "A One-Way Ticket to Francia: Constantinople, Rome and Northern Gaul in the Mid Seventh Century." In East and West in the Early Middle Ages, edited by Stefan Eders, Yaniv Fox, Yitzhat Hen, and Laury Sarti, 138-148. Cambridge: Cambridge University Press, 2019.

Mikhail, Alan. God's Shadow: Sultan Selim, His Ottoman Empire, and the Making of the Modern World. New York: Liveright Publishing, 2020.

Mitsiou, Ekaterina. "The Latin Empire of Constantinople (1204-1261): Rise and Fall of a Short-Term State in the Romania." In Short-term Empires in World History, edited by Robert Rollinger, Julian Degen, and Michael Gehler, 103-128. Wiesbaden: Springer VS, 2020.

Mullett, Margaret, and Robert G. Ousterhout, eds. The Holy Apostles. A Lost Monument, a Forgotten Project, and the Presentness of the Past. Washington, D.C.: Dumbarton Oaks, 2020.

Mustafa, Emir. 18. Yüzyll İstanbul'u: Her Yanı ve Her Şeyiyle: Insan ve Toplum Hayatı - Varllklar ve Nesneler. Istanbul: Ketebe, 2020.

Nakiboğlu, Aslıhan. “İstanbul Vilayetinin 1333 (1917) Y1lı Bütçesi.” Külliyat Osmanlı Araştırmaları Dergisi, (2019): 39-106.

Necipoğlu, Gülru, Cemal Kafadar, and Cornell H. Fleischer, eds. Treasures of Knowledge: An Inventory of the Ottoman Palace Library (1502/3-1503/4), 2 vols. Leiden: Brill, 2019.

Necipoğlu, Gülru. "The Aesthetics of Empire: Arts, Politics, and Commerce in the Construction of Sultan Süleyman's Magnificence." In The Battle for Central Europe: The Siege of Szigetvár and the Death of Süleyman the Magnificent and Miklós Zrinyi (1566), edited by Pál Fodor, 115-158. Leiden: Brill, 2019.

_. "The Spatial Organization of Knowledge in the Ottoman Palace Library: An Encyclopedic Collection and Its Inventory," and "Appendix IIl with Plates from Manuscripts at the Topkap Palace Museum Library." In Treasures of Knowledge: An Inventory of the Ottoman Palace Library (1502/3-1503/4), edited by Gülru Necipoğlu, Cemal Kafadar and Cornell H. Fleischer, 1-77, 1011-1075. Leiden, Boston: Brill, 2019.

—. "Transregional Connections: Architecture and the Construction of Early Modern Islamic Empires." In The Art \& Culture of Mughal India: New Studies, edited by Roda Ahluwalia, 254-285. New Delhi: Niyogi Books, 2020.

Nilsson, Ingela. Writer and Occasion in Twelfth-Century Byzantium. The Authorial Voice of Constantine Manasses. Cambridge: Cambridge University Press, 2020.

Niyazioğlu, Aslı. 17. Yüzyll İstanbul'unda Rüyalar ve Hayatlar. Istanbul: Doğan Yayınevi, 2020.

Nu'mānī, Shiblī, and Gregory Maxwell Bruce. "Summary History and Brief Circumstances of Constantinople.” In Turkey, Egypt, and Syria: A Travelogue, 41-122. Syracuse: Syracuse University Press, 2020.

Okçuoğlu, Agah Tarkan, ve Baha Tanman. "Nusretiye Camii Kalemişleri.” In Nusretiye Külliyesi-Bir Kültür Mirasinın Restorasyonu 2012-2017, edited by Murat Sav, 135-152. Istanbul: Vakıflar Genel Müdürlügü Yayınlar1, 2019.

Okçuoğlu, Tarkan. Hayal ve Gerçek Arasında: Osmanlı Resminde İstanbul İmgesi, 18. ve 19. Yüzyllar. Istanbul: İstanbul Araştırmaları Enstitüsü, 2020.

O'Loughlin, Katrina. Women, Writing, and Travel in the Eighteenth Century. Cambridge: Cambridge University Press, 2020.

Olsen, Robert J. “The Last Arab Siege of Constantinople (717-718): A Neglected Source.” Greek, Roman and Byzantine Studies 6o, no. 3 (2020): 425-443.

Ousterhout, Robert G. Eastern Medieval Architecture. The Building Traditions of Byzantium and Neighboring Lands. Oxford: Oxford University Press, 2019. 
Örs, İlay Romain. İstanbullu Rumlar ve 1964 Sürgünleri: Türk Toplumunun Homojenleşmesinde Bir Dönüm Noktası. Istanbul: İletişim Yayınları, 2019.

Özgüleş, Muzaffer. “Belgeler Işı̆̆ında Gülnuş Emetullah Sultan'ın Galata'da Yaptırdığı Çeşmeler.” Tasarım Kuram 16, no. 30 (2020): 27-38. https://doi.org/10.23835/tasarimkuram.239605.

Özgümüş, Ferudun. "Beyazıt'taki Orta Bizans Dönemi Kilisesi Kalıntısı." Restorasyon 18 (2019): 24-31.

Özkaya, Hatice Gökçen. "İstanbul'da On Yedinci Yüzyıl Evlerinde Yaşama Mekânları.” YILLIK: Annual of Istanbul Studies 1 (2019): 45-59.

Özlü, Nilay. "Silent Guardians of the Regime: The 'Lost' Police Stations of the Topkapı Palace." YILLIK: Annual of Istanbul Studies 1 (2019): 61-80.

Pal-Lapinski, Piya. "'Byron Pasha' in Istanbul with Mozart and Rossini: The Seductions of Ottoman Sovereignty." Byron Journal 48, no. 1 (2020): 1-15.

Palabiyık, Nil. "A Public Debate on Cyril of Alexandria's Views on the Procession of the Holy Spirit in Seventeenth-Century Constantinople: the Jesuit Reaction to Nicodemos Metaxas's Greek Editions." International Journal of the Classical Tradition 27, no. 3 (2020): 427-448.

Papastavrou, Elena. "Osmosis in Ottoman Constantinople: The Iconography of Greek Church Embroidery." In The Hidden Life of Textiles in the Medieval and Early Modern Mediterranean, vol. 3, edited by Nikolaos Vryzidis, 205-230. Turnhout: Brepols, 2020. https://doi.org/10.1484/M.MPMAS-EB.5.120559.

Parlak, Deniz. Laikleşme Sürecinde Camiler: Geç Osmanlidan Erken Cumhuriyet'e. Istanbul: Iletişim Yayınlar1, 2020.

Peirce, Leslie. Hürrem Sultan. Translated by Renan Akman. Istanbul: İş Bankası Kültür Yayınları, 2019.

Pentcheva, Bissera V., ed. Icons of Sound: Voice, Architecture, and Imagination in Medieval Art. New York: Routledge, 2020.

Polat, Gülten, and Özden Saygılı. "İstanbul'da Eski bir Mısır Dikilitaşının Koruma Amaçlı Yapısal Değerlendirilmesi." Yerbilimleri 41, no. 2 (2020): 169-182.

Poulos, Panagiotis C. "Spaces of Intercommunal Musical Relations in Ottoman Istanbul." YILLIK: Annual of Istanbul Studies 1 (2019): 181-189.

Praet, Raf. "Malalas and Erudite Memory in Sixth-Century Constantinople." In Die Weltchronik des Johannes Malalas im Kontext Spätantiker Memorialkultur, edited by Jonas Borsch, Olivier Gengler, and Mischa Meier, 219-239. Stuttgart: Franz Steiner Verlag, 2019.

Prazniak, Roxann. "Constantinople in Rum (Byzantium)." In Sudden Appearances: The Mongol Turn in Commerce, Belief, and Art, 55-78. Honolulu: University of Hawaii Press, 2019.

Quiroga Puertas, Alberto J. The Dynamics of Rhetorical Performances in Late Antiquity. London: Routledge, 2019.

Reher, David M. "Constantinople in the Iberian Imagination: 1400-1650." PhD diss., University of Chicago, 2020.

Riehle, Alexander. A Companion to Byzantine Epistolography. Leiden: Brill, 2020.

Rottman, Susan Beth, Ivan Josipovic, and Ursula Reeger. "Beyond Legal Status: Exploring Dimensions of Belonging among Forced Migrants in Istanbul and Vienna." Social Inclusion 8, no. 1 (2020): 241-251.

Russell, Norman, ed. and trans. Gregory Palamas: The Hesychast Controversy and the Debate with Islam. Liverpool: Liverpool University Press, 2020.

Rüstem, Ünver. "Piety and Presence in the Postclassical Sultanic Mosque." In Historicizing Sunni Islam in the Ottoman Empire, c. 1450-c. 1750, edited by Tijana Krstić and Derin Terzioğlu, 376-420. Leiden: Brill, 2020. https://doi.org/10.1163/9789004440296_012.

Sághy, Marianne, and Robert Ousterhout, eds. Piroska and the Pantokrator: Dynastic Memory, Healing and Salvation in Komnenian Constantinople. Budapest: Central European University Press, 2019.

Sankır, Hasan. "Construction of Gender Roles in 17th-Century Ottoman Dancing Boys (Köçeks)." Asian Journal of Social Science 48, no. 1/2 (2020): 44-68. https://doi.org/10.1163/15685314-04801004.

Sariyannis, Marinos. "Unseen Rebels: The 'Mob' of Istanbul as a Constituent of Ottoman Revolt, Seventeenth to Early Nineteenth Centuries." In Turkish Historical Review 10, no. 2/3 (March 2020): $155-188$.

Sav, Murat, ed. Nusretiye Külliyesi-Bir Kültür Mirasının Restorasyonu 2012-2017. Istanbul: Vakıflar Genel Müdürlüğü Yayınları, 2019.

Selvi, Hilal, and Pınar Erkan Bursa. "İstanbul Büyükada Maden Mahallesi Köşklerinde Art Nouveau Üslubunun Kullanımı.” Modular Journal 3, no. 1 (2020): 58-75. 
Shamel, Mir Shafiq. "Hafez of Shiraz, Constantinople, and Weltliteratur." In A Companion to World Literature, edited by Ken Seigneurie et al. London: Wiley-Blackwell, 2020.

https://doi.org/10.1002/9781118635193.ctwloo89.

Slootjes, Daniëlle and Mariette Verhoeven, eds. Byzantium in Dialogue with the Mediterranean: History and Heritage. Leiden: Brill, 2019

Sooyong, Kim. "Evliya Çelebi's Book of Travels: An Ottoman Experiment in Geographical Encyclopedism." In A Companion to World Literature, edited by Ken Seigneurie et al. London: Wiley-Blackwell, 2020. https://doi.org/10.1002/9781118635193.ctwloo89.

Sönmez, Ece, and Pulat Deniz Mazlum. "Restoration of the Greek Orthodox Churches at the End of the 19th Century in Istanbul: Case of Galatasaray Panagia Church." International Journal of Architecture and Planning 8, no. 1 (2020): 357-382.

Strutz, Julia. "Spiriting Away the Bad Urbanite: From the Topkapı Bus Terminal to the Panorama Museum 1453." In Doing Tolerance: Urban Interventions and Forms of Participation, edited by Castro Varela María Do Mar, and Ülker Barış, 136-153. Opladen: Verlag Barbara Budrich, 2020.

Sünnetçioğlu, H. Evren. "Attendance at the Five Daily Congregational Prayers, Imams and Their Communities in the Jurisprudential Debates during the Ottoman Age of Sunnitization." In Historicizing Sunni Islam in the Ottoman Empire, c. 1450-c. 1750, edited by Tijana Krstić and Derin Terzioğlu, 341-375. Leiden: Brill, 2020. https://doi.org/10.1163/9789004440296_011.

Şahin, Baha Mücahid. "The Effect of Interest and Rent Income of the Foundations of Ottoman Istanbul Eyüp Region on Cash Capitals: Panel Data Analysis (1769-1773)." Istanbul Journal of Economics 70, no. 1 (2020): 183-203. https://doi.org/10.26650/ISTJECON2020-0009.

Şencan Gürtunca, Evrim. "Fransızca Basında 1908 Yılı İstanbul Yangınları: Le Moniteur Oriental Örneği." Karadeniz Araştırmaları Enstitüsü Dergisi 6 (2020): 81-102.

Tağmat, Çă̆la Derya. "Birinci Dünya Savaşı Yıllarında İstanbul Rumlarının Sosyo-Kültürel Faaliyetleri.” BELLEK Uluslararası Tarih ve Kültür Araştırmaları Dergisi 2, no. 1 (2020): 89-105.

Taşçı, Faruk, and Başak Işıl Alpar. "Administrating Social Policies of a City: Modeling From Esenler District in İstanbul." Çalışma ve Toplum Dergisi 41, no. 1 (2020): 31-71.

Tchihatchef, Pierre De. Istanbul ve Boğaziçi. Translated by Ali Berktay. Istanbul: Türkiye İş Bankası Kültür Yayınları, 2019.

Teller, Adam. "On the Istanbul Slave Market." In Rescue the Surviving Souls: The Great Jewish Refugee Crisis of the Seventeenth Century, 124-131. Princeton: Princeton University Press, 2020.

Temel, M. Kemal. “The 1918 'Spanish Flu' Pandemic in the Ottoman Capital, Istanbul.” Canadian Bulletin of Medical History 37, no. 1 (2020): 195-231.

The Chronicle of the Logothete. Translated with commentary by Staffan Wahlgren. Oxford: Oxford University Press, 2020.

Thomov, Thomas. "A Dragon Slayer Graffito Drawing in Hagia Sophia, Constantinople (modern Istanbul).” Byzantinoslavica - Revue internationale des Études Byzantines 77, no. 1/2 (2019): 291-303.

Tougher, Shaun, ed. The Emperor in the Byzantine World: Papers from the Forty-Seventh Spring Symposium of Byzantine Studies. London: Routledge, 2019.

Travlos, Konstantinos. Salvation and Catastrophe: The Greek-Turkish War, 1919-1922. Lanham: Lexington Books, 2020.

Tsavdaroglou, Charalampos. "The Refugees' Right to the Center of the City and Spatial Justice: Gentrification vs Commoning Practices in Tarlabaş1-Istanbul." Urban Planning 5, no. 3 (2020): 230-240. http://dx.doi.org/10.17645/up.v5i3.3098.

Tulke, Julia. "Archiving Dissent: (Im)material Trajectories of Political Street Art in Istanbul and Athens." In The Aesthetics of Global Protest: Visual Culture and Communication, edited by McGarry Aidan, Erhart Itir, Eslen-Ziya Hande, Jenzen Olu, and Korkut Umut, 121-140. Amsterdam: Amsterdam University Press, 2020.

Turan, Ömer. "Resistance and Gift-Giving: Gezi Park." In Doing Tolerance: Urban Interventions and Forms of Participation, edited by Barış Ülker and María do Mar Castro Varela, 171-193. Leverkusen: Barbara Budrich Publishers, 2020.

Turan Tüylüoğlu, Büşra, ve Murat Şentürk. "Sermaye Biçimi Olarak Mekânsal Sermaye ve Yükseköğretim Mezunu Gençlerin Deneyimleri Üzerine Nitel Bir Araştırma: İstanbul/Gazi Mahallesi Örneği.” Gençlik Araştırmaları Dergisi 8 (2020): 47-73.

Türkoğlu, ilknur. "İstanbul'da Kentsel Hafızanın Devamlılı̆̆ı: Pantokrator Manastırı ile Süleymaniye 
Külliyesi'nin Karşılaştırması." Vakıflar Dergisi 53 (2020): 199-219.

Uğuryol, Drahşan. "Evaluation of Preservation Problems of the Historical Gardens and Their Architectural Elements Considering the Palaces and Pavilions in Istanbul." METU Journal of the Faculty of Architecture 37 (2020): 225-251.

Ural, Tülin. "Orhan Pamuk Anlatılarındaki Yeme İçme Sahneleri Bağlamında, İstanbul Burjuvazisi Ne Yer, Nerede Yer, Nasil Yer, Neyi Temsil Eder?” Istanbul University Journal of Sociology 40, no. 1 (2020): 397-418.

Uremovic, Danijel. "Two Prosōpa, one Prosōpon; the Christology of Nestorius of Constantinople." Aristos 5, no. 1 (2020): 1-13.

Uysal, Ahmet Can. 1793 ve 1802 Yıllarında İstanbul Klyıları (Defter-i Bostancı). Istanbul: Hoşgörü Yayınları, 2019.

Üçoğlu, Murat. “Massive Housing and Nature's Limits? The Urban Political Ecology of Istanbul's Periphery." Massive Suburbanization: (re)building the Global Periphery, edited by K. Murat Güney, Roger Keil, and Murat Üçoğlu, 201-221. Toronto: University of Toronto Press, 2019.

Ülker, Erol. Mütareke'nin Illk Yıllarında İstanbul'da Direniş ve Sol, 1918-1920. Istanbul: Sosyal Tarih Yayınları, 2020.

Üre, P1nar. Reclaiming Byzantium: Russia, Turkey and the Archaeological Claim to the Middle East in the 19th Century. London: I.B. Tauris, 2020.

Vatin, Nicolas. "Un provincial dans les bureaux de la capitale." In Les Ottomans par eux-mêmes, edited by Elisabetta Borromeo and Nicolas Vatin, 201-206. Paris: Les Belles Lettres, 2020.

Van Gageldonk, Cansu. "Cinema Emek, Cinema Labour, Cinema Travail: The Revitalization of Istanbul's Urban Past and the Emek Theater as a Lieu de Mémoire." In Animation and Memory, edited by Maarten van Gageldonk, László Munteán, and Ali Shobeiri, 181-198. Cham: Palgrave Macmillian, 2020. https://doi.org/10.1007/978-3-030-34888-5.

Weber, Halcyon. "Compromise and Coercion: Imperial Motives behind Justinianic Legislation in SixthCentury Constantinople," In Empire and Legal Thought: Ideas and Institutions from Antiquity to Modernity, edited by Edward Cavanagh, 125-166. Leiden: Brill, 2020.

Wharton-Durgaryan, Alyson, "'I have the honour to inform you that I have just arrived from Constantinople': Migration, Identity and Commodity Disavowal in the Formation of the Islamic Art Collection at the V\&A." Museum and Society 18, no. 2 (2020): 258-279.

Yanar, Burcu, and Gülden Erkut. "Belediyelerin Suriyeli Mültecilere Yönelik Politikaları: İstanbul Örneği." Şehir ve Medeniyet Dergisi 6, no. 11 (2020): 191-214. .

Yaşar Tunç, Fatma. "ikinci Meşrutiyet Döneminde Bir Çöpçatanlık Ajansı: Teshil-i İzdivaç ve Teşkil-i Aile İdarehanesi.” Selçuk Üniversitesi Türkiyat Araştırmaları Dergisi 49 (2020): 419-436.

Yaşar, Ahmet. "1766 Tarihli Bir Hamam Defterine Göre İstanbul Vakıf Hamamları.” Vakıflar Dergisi 53 (2020): 67-99.

Yaşar, Ahmet. "Stratford Canning Albümü: 1809 İstanbulu'nda Mekân Tahayyülleri.” International Journal of History 12, no. 4 (August 2020): 2199-2218.

Yerasimos, Marianna. İstanbullu Rum Bir Ailenin Mutfak Serüveni: Tarifler, Hikâyeler, Anılar. Istanbul: Yapı Kredi Yayınları, 2019.

Yıldırım, Nuran, and Hakan Ertin. "1893-1895 İstanbul Kolera Salgınında Avrupalı Uzmanlar ve Osmanlı Devleti’nde Sağlık Modernizasyonuna Katkıları.” Anadolu Kliniği Tıp Bilimleri Dergisi 25 (2020): 85-101.

Yllgür, Egemen. "Formation of Informal Settlements and the Development of the Idiom Teneke Mahalle in the Late-Ottoman Istanbul." Journal of Urban History (August 2020): 1-30.

Yiğit, Nevzat. "Üsküdar'da Konumlanmış Bir Ocak: Tazıcılar Ocağı.” Eskiyeni 40 (2020): 321-340.

Yüzer, Canse. "Rebii Gorbon: Mimarlık ve Seramik Arasında Bir Kariyer.” Master's thesis, İstanbul Teknik Üniversitesi, 2019.

Zenbilci, İlkgül. “Orta Bizans Dönemi’nde Başkent Konstantinopolis’ten Taşraya Aktarılan Mimari Anlayış: Panagia Ton Khalkeon Kilisesi Örneği.” Ortaçağ Araştırmaları Dergisi 3, no. 1 (2020): 193-215. 